Supporting information for:

\title{
Synthesis and optical resolution of 9,9'-spirobifluorene-1,1'-diol
}

\author{
Xu Cheng, Gou-Hua Hou, Jian-Hua Xie, Qi-Lin Zhou* \\ State Key Laboratory and Institute of Elemento-oragnic Chemistry, \\ Nankai University Tianjin 300071, China
}

\section{General:}

All reactions and manipulations were performed using standard Schlenk techniques. THF was distilled from sodium benzophenone ketyl. $\mathrm{CH}_{2} \mathrm{Cl}_{2}$ was distilled from $\mathrm{CaH}_{2}$. Melting points were measured on a RY-I apparatus and uncorrected. ${ }^{1} \mathrm{H},{ }^{13} \mathrm{C}$ and ${ }^{31} \mathrm{P}$ NMR spectra were recorded on a Varian Mercury Vx-300 spectrometer or Bruker $300 \mathrm{MHz}$. Chemical shifts were reported in ppm down field from internal $\mathrm{Me}_{4} \mathrm{Si}$. Optical rotations were determined using a Perkin Elmer $341 \mathrm{MC}$ polarimeter. Elemental analyses were performed on the Yanaca CDRDER MT-3 instrument. Mass spectra were recorded on the VG-7070E spectrometer. HPLC analyses were performed using a Hewlett Packard Model HP 1100 Series. X-ray diffraction analysis was performed on a Bruker smart-1000 X-ray diffraction meter.

\section{Synthesis of racemic 9,9'-spirobifluorene-1,1'-diol}

\section{Preparation of 2-bromo-3'-methoxybiphenyl (1)}

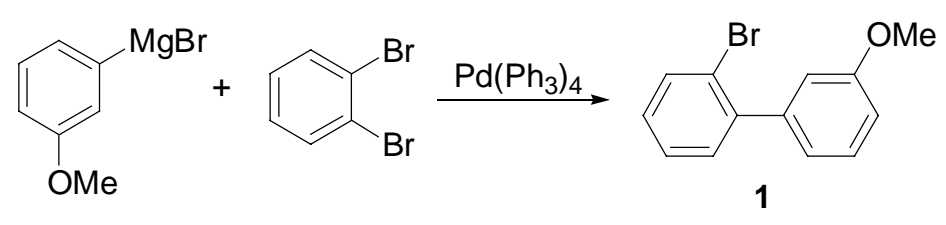

A solution of 3-methoxyphenylmagnesium bromide was prepared from magnesium powders (2.1 g, $89 \mathrm{mmol})$ and 1-bromo-3-methoxybenzene $(16.6 \mathrm{~g}, 89 \mathrm{mmol})$ in $100 \mathrm{~mL}$ of THF. This solution was added to the mixture of 1,2-dibromobenzene $(20.0 \mathrm{~g}, 92 \mathrm{mmol})$ and tetrakis(triphenylphosphine)palladium $(1.5 \mathrm{~g}, 1.3 \mathrm{mmol})$ in $100 \mathrm{~mL}$ of THF. The resulted mixture was stirred for $48 \mathrm{~h}$ at $40{ }^{\circ} \mathrm{C}$ and was hydrolyzed with saturated $\mathrm{NH}_{4} \mathrm{Cl}$. Extraction with $\mathrm{Et}_{2} \mathrm{O}$, dryness over $\mathrm{MgSO}_{4}$ and concentration under reduced pressure yielded the crude product. Chromatography of crude product on silica gel with PE/EA (30:1) gave compound 1 as a colorless liquid (14.0 g, 60\%). ${ }^{1} \mathrm{H} \mathrm{NMR}\left(300 \mathrm{MHz}, \mathrm{CDCl}_{3}\right) \delta 3.87$ (s, 3H, Ar-OCH $), 6.98$ $(\mathrm{d}, 1 \mathrm{H}, J=7.5 \mathrm{~Hz}, \mathrm{Ar}-\mathrm{H}), 7.13-7.58(\mathrm{~m}, 5 \mathrm{H}, \mathrm{Ar}-\mathrm{H}), 7.59$ (d, $2 \mathrm{H}, J=7.2 \mathrm{~Hz}, \mathrm{Ar}-\mathrm{H}) ;{ }^{13} \mathrm{C} \mathrm{NMR}$ 
$\left(75 \mathrm{MHz}, \mathrm{CDCl}_{3}\right) \delta 55.5,113.5,115.3,122.1,122.8,127.6,129.0,129.3,131.4,133.4,142.6$, 159.4; MS (EI) m/z 263 and $264\left(\mathrm{M}^{+}\right)$; Anal. Calcd for $\mathrm{C}_{13} \mathrm{H}_{11} \mathrm{BrO}$ : C, 59.34; H, 4.21. Found: C, 59.28; H, 4.18.

\section{Preparation of bis(3'-methoxybiphenyl-2-yl)methanone (10)}

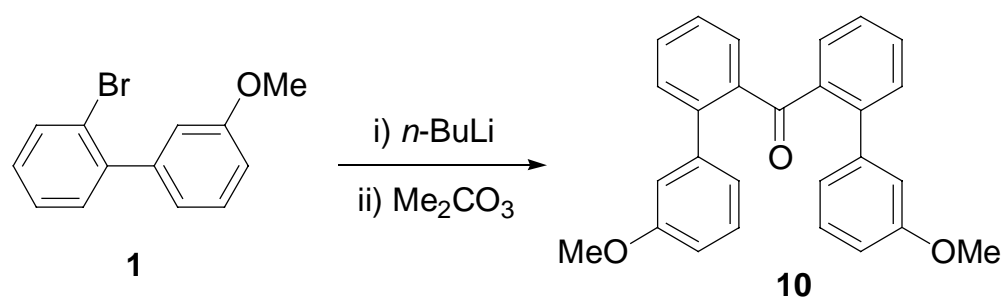

To a solution of 1 (15.1 g, $57.4 \mathrm{mmol})$ in $120 \mathrm{~mL}$ of THF was added $n$-BuLi (34.3 mL, 60 mmol, $1.8 \mathrm{M}$ in Hexane) at $-78{ }^{\circ} \mathrm{C}$, and the mixture was stirred for $0.5 \mathrm{~h}$. After slowly addition of methyl carbonate $(2.3 \mathrm{~g}, 25.7 \mathrm{mmol})$ in $40 \mathrm{~mL}$ of THF, this reaction mixture was gradually warmed to $-45 \sim-40{ }^{\circ} \mathrm{C}$ and kept at this temperature for $3 \mathrm{~h}$ to give a yellow slurry. This slurry was warmed to room temperature, hydrolyzed with saturated $\mathrm{NH}_{4} \mathrm{Cl}$ and evaporated under reduced pressure to remove the solvent. The residue was dissolved in $\mathrm{CH}_{2} \mathrm{Cl}_{2}$, washed with dilute $\mathrm{HCl}$ and brine, dried over $\mathrm{MgSO}_{4}$, concentrated under reduced pressure to offer a yellow solid. The solid was recrystallized with EA to give compound $\mathbf{1 0}$ as a white solid $(7.1 \mathrm{~g}$, 75\%). M.p. 159 160 ${ }^{\circ} \mathrm{C} ;{ }^{1} \mathrm{H}$ NMR $\left(300 \mathrm{MHz}, \mathrm{CDCl}_{3}\right) \delta 3.74$ (s, 6H, Ar-OCH$)_{3}, 6.64(\mathrm{~s}, 2 \mathrm{H}$, Ar-H), 6.69 (t, 4H, J = 7.5 Hz, Ar-H), 7.06-7.20 (m, 6H, Ar-H), 7.29-7.39 (m, 4H, Ar-H); ${ }^{13} \mathrm{C}$ NMR $\left(75 \mathrm{MHz}, \mathrm{CDCl}_{3}\right) \delta 55.1,112.7,114.5,121.5,126.7,128.9,129.9,130.4,130.5,139.1$, 141.2, 141.8, 158.9, 200.5; MS (EI) m/z $394\left(\mathrm{M}^{+}\right)$; Anal. Calcd for $\mathrm{C}_{27} \mathrm{H}_{22} \mathrm{O}_{3}: \mathrm{C}, 82.21 ; \mathrm{H}$, 5.62. Found: C, 82.26; H, 5.71.

\section{Preparation of bis(2'-bromo-5'-methoxybiphenyl-2-yl)methanone (11)}

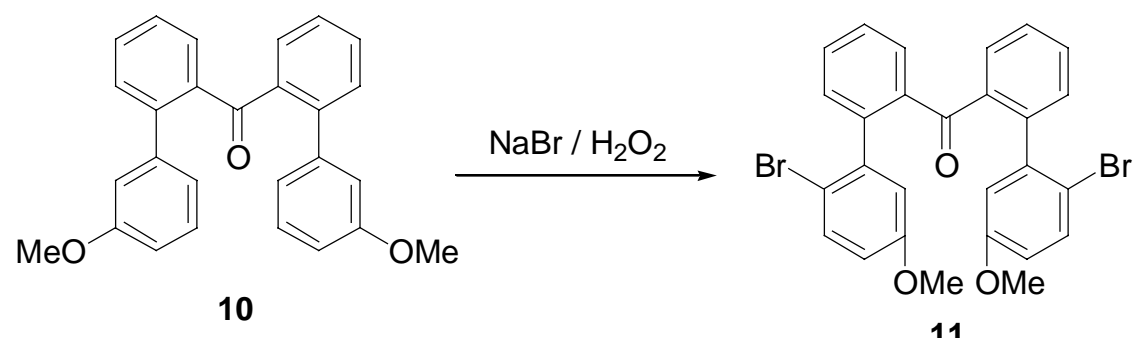

11

Sodium bromide $(5.2 \mathrm{~g}, 50.8 \mathrm{mmol})$ and the well-powdered $10(10.0 \mathrm{~g}, 25.4 \mathrm{mmol})$ were added to $300 \mathrm{~mL}$ of acetic acid to give a suspension. Hydrogen peroxide (30\% aqueous, $15 \mathrm{~mL}$, $0.44 \mathrm{~mol}$ ) was added to this suspension. After vigorously stirring for $6 \mathrm{~h}$, the mixture was diluted with water and extracted with $\mathrm{CH}_{2} \mathrm{Cl}_{2}(3 \times 30 \mathrm{~mL})$. The combined organic phase was washed with aqueous $\mathrm{NaHCO}_{3}$ and brine, dried over $\mathrm{MgSO}_{4}$ and concentrated under reduced pressure to give a light-yellow solid 11 (14.2 g, 100\%). M.p. $158 \sim 160{ }^{\circ} \mathrm{C} ;{ }^{1} \mathrm{H} \mathrm{NMR}(300 \mathrm{MHz}$, $\left.\mathrm{CDCl}_{3}\right) \delta 3.69\left(\mathrm{~s}, 3 \mathrm{H}, \mathrm{Ar}-\mathrm{OCH}_{3}\right), 3.37$ (s, 3H, Ar-OCH ${ }_{3}$, 6.63-6.69 (m, 4H, Ar-H), 7.19-7.21 
(m, 4H, Ar-H), 7.34-7.50 (m, 5H, Ar-H), 7.59 (d, 1H, J= 7.8 Hz, Ar-H); ${ }^{13} \mathrm{C}$ NMR $(75 \mathrm{MHz}$, $\left.\mathrm{CDCl}_{3}\right) \delta 55.4,113.7,113.8,114.4,115.3,116.5,116.7,127.2,127.3,129.1,130.0,130.4$, 130.7, 131.0, 131.1, 132.8, 133.0, 137.9, 139.6, 139.7, 140.6, 141.8, 142.4, 158.3, 196.4; MS (EI) $\mathrm{m} / \mathrm{z} 473\left(\mathrm{M}^{+}-\mathrm{Br}\right)$; Anal. Calcd for $\mathrm{C}_{27} \mathrm{H}_{20} \mathrm{Br}_{2} \mathrm{O}_{3}$ : C, 58.72; H, 3.65. Found: C, 58.54; H, 3.50 .

\section{Preparation of 4,4'-dibromo-1,1'-dimethoxy-9,9'-spirobifluorene (8)}

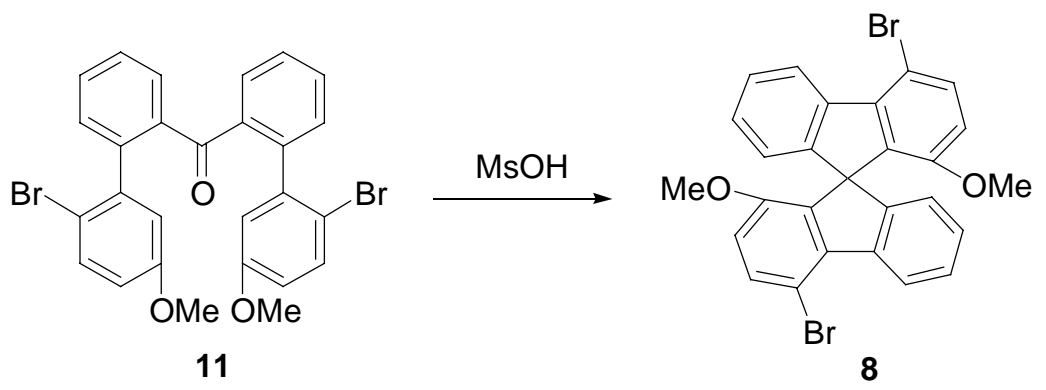

The compound 11 (14.2 g, $25.7 \mathrm{mmol})$ was added to $400 \mathrm{~mL}$ of methanesulfonic acid and was stirred vigorously at $40 \sim 50{ }^{\circ} \mathrm{C}$ for $5 \mathrm{~h}$. The reaction mixture was poured into ice-cold water, extracted with $\mathrm{CH}_{2} \mathrm{Cl}_{2}(3 \times 30 \mathrm{~mL})$. The organic phase was washed with aqueous $\mathrm{NaHCO}_{3}$ and brine, dried over $\mathrm{MgSO}_{4}$, concentrated under reduced pressure to offer a yellow solid. This solid was washed with EA to give compound $\mathbf{8}$ as a white powder $(10.0 \mathrm{~g}, 73 \%)$. M.p. $158 \sim 160{ }^{\circ} \mathrm{C} ;{ }^{1} \mathrm{H}$ NMR $\left(300 \mathrm{MHz}, \mathrm{CDCl}_{3}\right) \delta 3.22$ (s, 6H, Ar-OCH 3 ), 6.54 (d, 2H, J=8.4 $\mathrm{Hz}, \operatorname{Ar}-\mathrm{H}), 6.63$ (d, 2H, J=7.2 Hz, Ar-H), 7.11 (t, 3H, J=7.5 Hz, Ar-H), 7.36 (t, 3H, J = 7.5 $\mathrm{Hz}, \mathrm{Ar}-\mathrm{H}), 7.47$ (d, 2H, $J=8.7 \mathrm{~Hz}, \mathrm{Ar}-\mathrm{H}), 8.63$ (d, 2H, $J=7.5 \mathrm{~Hz}, \mathrm{Ar}-\mathrm{H}) ;{ }^{13} \mathrm{C}$ NMR $(75 \mathrm{MHz}$, $\left.\mathrm{CDCl}_{3}\right) \delta$ 56.0, 103.2, 107.6, 112.4, 119.6, 122.6, 123.1, 126.9, 128.0, 133.6, 137.0, 141.3, 148.0, 155.0; MS (EI) m/z $534\left(\mathrm{M}^{+}\right)$; Anal. Calcd for $\mathrm{C}_{27} \mathrm{H}_{18} \mathrm{Br}_{2} \mathrm{O}_{2}: \mathrm{C}, 60.70 ; \mathrm{H}, 3.40$. Found: C, 60.72; H, 3.46.

\section{Preparation of $1,1^{\prime}$-dimethoxy-9,9'-spirobifluorene (12)}

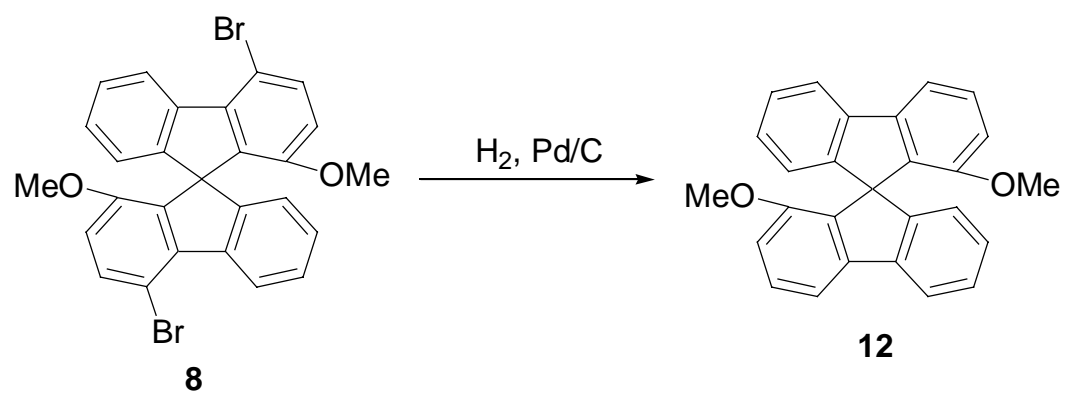

To a solution of the compound $8(7.2 \mathrm{~g}, 13.5 \mathrm{mmol})$ in $120 \mathrm{~mL}$ of THF was added tetrabutylammonium bromide $(2.9 \mathrm{~g}, 9 \mathrm{mmol})$, potassium carbonate $(13.1 \mathrm{~g}, 95 \mathrm{mmol})$ in 58 $\mathrm{mL}$ distilled water and palladium on coal $(0.95 \mathrm{~g}, 10 \%, 0.9 \mathrm{mmol})$. The mixture was stirred and hydrogenated by bubbling hydrogen at $35 \sim 40{ }^{\circ} \mathrm{C}$ for $4 \mathrm{~h}$. After cooling to room 
temperature, the reaction mixture was filtrated through celite and extracted with $\mathrm{CH}_{2} \mathrm{Cl}_{2}(3 \times 30$ $\mathrm{mL}$ ). The organic phase was dried over $\mathrm{MgSO}_{4}$, passed through a silica gel pad. Evaporation of solvent under reduced pressure produced compound 12 as a white solid (5.4 g, 100\%). M.p. 214 216 ${ }^{\circ} \mathrm{C} ;{ }^{1} \mathrm{H}$ NMR (300 MHz, d 6 -acetone) $\delta 3.24\left(\mathrm{~s}, 6 \mathrm{H}, \mathrm{Ar}-\mathrm{OCH}_{3}\right), 6.52(\mathrm{~d}, 2 \mathrm{H}, J=7.5 \mathrm{~Hz}$, Ar-H), 6.76 (d, 2H, $J=8.1 \mathrm{~Hz}$, Ar-H), 7.06 (t, 2H, $J=7.5 \mathrm{~Hz}, \mathrm{Ar}-\mathrm{H}), 7.29-7.40$ (m, 4H, Ar-H), 7.57 (d, 2H, $J=7.5 \mathrm{~Hz}, \mathrm{Ar}-\mathrm{H}), 7.89(\mathrm{~d}, 2 \mathrm{H}, J=7.8 \mathrm{~Hz}, \mathrm{Ar}-\mathrm{H}) ;{ }^{13} \mathrm{C}$ NMR $\left(75 \mathrm{MHz}, \mathrm{CDCl}_{3}\right) \delta$ $55.8,111.1,112.6,119.8,122.9,127.0,127.4,129.0,134.6,142.0,144.2$, 148.2, 156.1; MS (EI) m/z $376\left(\mathrm{M}^{+}\right)$; Anal. Calcd for $\mathrm{C}_{27} \mathrm{H}_{20} \mathrm{O}_{2}$ : C, 86.14; H, 5.36. Found: C, 85.96; H, 5.47.

\section{Preparation of $1,1^{\prime}$-dihydroxy-9,9'-spirobifluorene (13)}

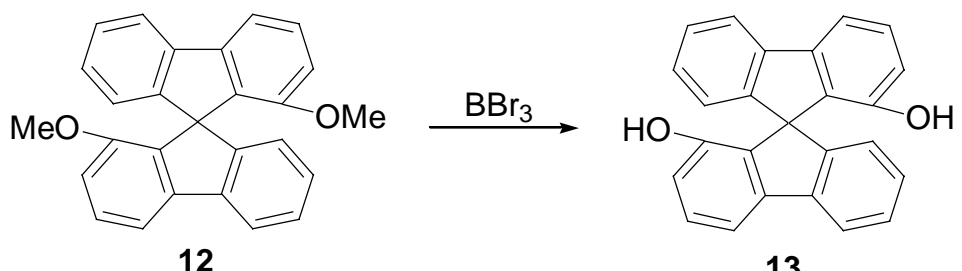

Tribromoboron $(7.2 \mathrm{~mL}, 44 \mathrm{mmol})$ in $18 \mathrm{~mL}$ of $\mathrm{CH}_{2} \mathrm{Cl}_{2}$ was added dropwise to a solution of the compound 12 ( $4.0 \mathrm{~g}, 11 \mathrm{mmol})$ in $74 \mathrm{~mL}$ of $\mathrm{CH}_{2} \mathrm{Cl}_{2}$ at $-78{ }^{\circ} \mathrm{C}$. The mixture was stirred overnight and warmed spontaneously during the reaction. The reaction mixture was diluted with $\mathrm{CH}_{2} \mathrm{Cl}_{2}(50 \mathrm{~mL})$, washed with aqueous $\mathrm{NaHSO}_{3}$ and brine successively, and dried over $\mathrm{MgSO}_{4}$. Concentration under reduced pressure offered a brown solid. Recrystallization of the crude product with acetone and petroleum ether gave the compound $\mathbf{1 3}$ as a white solid $(3.0 \mathrm{~g}$, 81\%). M.p. 289 291 ${ }^{\circ} \mathrm{C} ;{ }^{1} \mathrm{H}$ NMR (300 MHz, $\left.\mathrm{CDCl}_{3}\right) \delta 3.98$ (s, 2H, Ar-OH), 6.68 (d, $2 \mathrm{H}, J=$ $6.6 \mathrm{~Hz}, \mathrm{Ar}-\mathrm{H}), 6.78$ (d, 2H, J=7.5 Hz, Ar-H), 7.16 (t, 2H, J= 7.5 Hz, Ar-H), 7.33-7.43 (m, 4H, Ar-H), $7.50(\mathrm{~d}, 2 \mathrm{H}, J=7.5 \mathrm{~Hz}, \mathrm{Ar}-\mathrm{H}), 7.86(\mathrm{~d}, 2 \mathrm{H}, J=8.7 \mathrm{~Hz}, \mathrm{Ar}-\mathrm{H}) ;{ }^{13} \mathrm{C}$ NMR $(75 \mathrm{MHz}$, $\left.\mathrm{CDCl}_{3}\right) \delta 31.0,113.2,116.1,120.8,123.7,128.5,128.6,129.1,130.6,141.0,142.9,145.5$, 152.5; MS (EI) m/z $348\left(\mathrm{M}^{+}\right)$; Anal. Calcd for $\mathrm{C}_{25} \mathrm{H}_{16} \mathrm{O}_{2}: \mathrm{C}, 86.19 ; \mathrm{H}, 4.63$. Found: $\mathrm{C}, 85.99$; H, 4.66 .

\section{Resolution of racemic $1,1^{\prime}$-dihydroxy-9,9'-spirobifluorene}

The well-powdered racemic diol $\mathbf{1 3}(2.0 \quad \mathrm{~g}, \quad 5.7 \quad \mathrm{mmol})$ and $(2 R, 3 R)-\mathrm{N}, \mathrm{N}, \mathrm{N}^{\prime}, \mathrm{N}^{\prime}$-tetracyclohexyl- 2,3-dimethoxysuccinamide (14) (2.9 g, $\left.5.7 \mathrm{mmol}\right)$ were added to $16 \mathrm{~mL}$ of ethanol, and the mixture was stirred rapidly to give a clear solution. After a few minutes, white precipitate appeared. This slurry was stirred overnight and filtrated to give a white powder. The powder was dissolved in $50 \mathrm{~mL}$ of $\mathrm{Et}_{2} \mathrm{O}$ and washed with $1 \mathrm{~N} \mathrm{NaOH}$. The organic layer was dried over $\mathrm{MgSO}_{4}$ and concentrated under reduced pressure to recover the resolving reagent. The aqueous layer was acidified by concentrated $\mathrm{HCl}$ to $\mathrm{pH}=3$ and extracted with $\mathrm{CH}_{2} \mathrm{Cl}_{2}(3 \times 20 \mathrm{~mL})$. The $\mathrm{CH}_{2} \mathrm{Cl}_{2}$ phase was dried with $\mathrm{MgSO}_{4}$ and concentrated under reduced pressure to give the $\mathbf{1 3}(0.85 \mathrm{~g}, 85 \%$ based on one enantiomer) in $80 \%$ ee with $R$ configuration. 
By repeating the procedures of the inclusion and the decomposition mentioned above, $(R)-(+)-13(0.6 \mathrm{~g}, 60 \%)$ in $99 \%$ ee was obtained as a white solid. M.p. $290{ }^{\circ} \mathrm{C} ;[\alpha]^{25} \mathrm{D}=+39.2$ (c $\left.0.50, \mathrm{CHCl}_{3}\right)$.

The mother liquid of the resolution was concentrated under reduced pressure to give the $\mathbf{1 3}$, with $S$ isomer being predominant. The inclusion complex was decomposed by the procedure referred above and subjected to the resolution by $(2 S, 3 S)-\mathbf{1 4}$ to offer the $(S)-\mathbf{1 3}(0.73,73 \%$ based on one isomer) in $99 \%$ ee.

The ee values of the resolution products were determined by HPLC analysis on DAICEL OD-H column: $\mathrm{Hex} / i-\mathrm{PrOH}=85: 15$, flow $=0.7 \mathrm{~mL} / \mathrm{min}, \mathrm{t}_{R}=17.0 \mathrm{~min}, \mathrm{t}_{S}=26.3 \mathrm{~min}$ ).

\section{X-ray analysis of inclusion complex}

A single crystal of inclusion complex suitable for X-ray analysis was prepared by the recrystallization of the complex in ethanol. M.p. 184 186 ${ }^{\circ} \mathrm{C} ;{ }^{1} \mathrm{H}$ NMR $\left(300 \mathrm{MHz}, \mathrm{CDCl}_{3}\right) \delta$ 1.06-1.88 (m, 43H, hexyl and methyl in ethanol), 2.34-2.50 (m, 4H, N-CHR 2$), 3.41(\mathrm{~s}, 6 \mathrm{H}$, $\mathrm{OCH}_{3}$ ), 3.68-3.76 (m, 2H, $\mathrm{CH}_{2}$ in ethanol), 4.14 (s, 2H, HC-CO), 4.57 (s, 2H, Ar-OH), 6.68 (d, $2 \mathrm{H}, J=8.1 \mathrm{~Hz}, \mathrm{Ar}-\mathrm{H}), 6.78(\mathrm{~d}, 2 \mathrm{H}, J=7.5 \mathrm{~Hz}, \mathrm{Ar}-\mathrm{H}), 7.16(\mathrm{t}, 2 \mathrm{H}, J=7.5 \mathrm{~Hz}, \mathrm{Ar}-\mathrm{H}), 7.2-7.48$ (m, 4H, Ar-H), 7.49 (d, 2H, J=7.5 Hz, Ar-H), 7.85 (d, 2H, J=7.8 Hz, Ar-H); Anal. Calcd for $\mathrm{C}_{55} \mathrm{H}_{68} \mathrm{~N}_{2} \mathrm{O}_{6}: \mathrm{C}, 60.70 ; \mathrm{H}, 3.40$. Found: $\mathrm{C}, 60.72 ; \mathrm{H}, 3.36$. The structure and the crystal data are in Figure 1 and Table 1. The bond lengths and the bond angles are in cif file.

Figure $1 \mathrm{X}$-Ray structure of inclusion complex of $(R)-\mathbf{1 3}$ and $(2 R, 3 R)-\mathbf{1 4}$

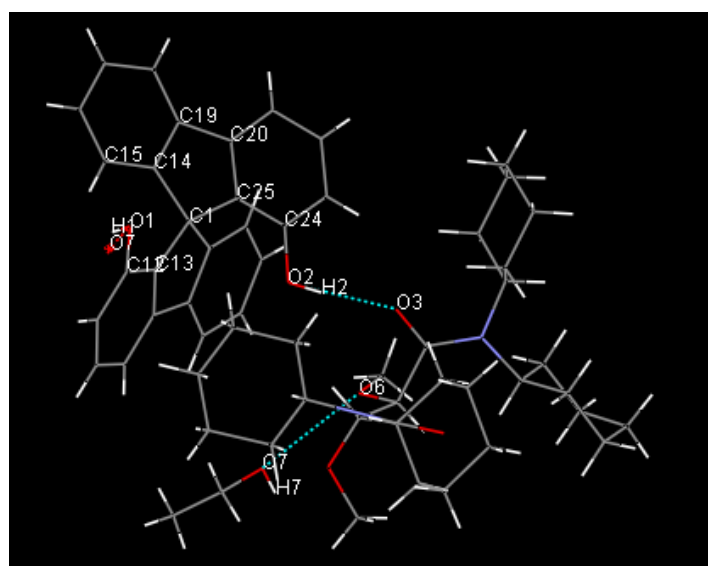


Table 1. Crystal data and structure refinement for inclusion complex $(R)-\mathbf{1 3}$ and $(2 R, 3 R)-\mathbf{1 4}$

$\begin{array}{ll}\text { Empirical formula } & \mathrm{C}_{57} \mathrm{H}_{74} \mathrm{~N}_{2} \mathrm{O}_{7} \\ \text { Formula weight } & 899.18 \\ \text { Temperature } & 293(2) \mathrm{K} \\ \text { Wavelength } & 0.71073 \AA \\ \text { Crystal system, space group } & \text { Monoclinic, } \mathrm{P} 2(1) \\ \text { Unit cell dimensions } & \mathrm{a}=9.718(3) \AA \quad \alpha=90^{\circ} \\ & \mathrm{b}=25.585(8) \AA \quad \beta=113.919(7)^{\circ} \\ & \mathrm{c}=11.268(4) \AA \quad \gamma=90^{\circ} \\ \text { Volume } & 2561.0(14) \AA^{3} \quad \\ \text { Z, Calculated density } & 2,1.166 \mathrm{Mg} \cdot \mathrm{m}^{3} \\ \text { Absorption coefficient } & 0.076 \mathrm{~mm} \mathrm{~m}^{-1} \\ \text { F(000) } & 972 \\ \text { Crystal size } & 0.22 \times 0.20 \mathrm{x} 0.18 \mathrm{~mm} \\ \text { Theta range for data collection } & 2.29 \text { to } 25.00^{\circ} \\ \text { Limiting indices } & -11 \leq \mathrm{h} \leq 11,-30 \leq \mathrm{k} \leq 30,-13 \leq 1 \leq 7 \\ \text { Reflections collected / unique } & 13219 / 8644[\mathrm{R}(\mathrm{int})=0.0754] \\ \text { Completeness to theta }=25.00 & 99.8 \% \\ \text { Absorption correction } & \mathrm{Semi}-\mathrm{empirical} \mathrm{from} \mathrm{equivalents} \\ \text { Max. and min. transmission } & 0.9865 \text { and } 0.9836 \\ \text { Refinement method } & \text { Full-matrix least-squares on } \mathrm{F}^{2} \\ \text { Data / restraints / parameters } & 8644 / 1 / 601 \\ \text { Goodness-of-fit on } \mathrm{F}^{2} & 0.951 \\ \text { Final R indices [I>2sigma(I)] } & \mathrm{R} 1=0.0687, \mathrm{wR} 2=0.0785 \\ \mathrm{R} \text { indices (all data) } & \mathrm{R} 1=0.2024, \mathrm{wR} 2=0.1083 \\ \text { Absolute structure parameter } & 2.6(14) \\ \text { Largest diff. peak and hole } & 0.154 \text { and }-0.148 \text { e. } \AA^{-3} \\ & \end{array}$

